\title{
The enzymatic activity of the small intestine mucosa of young pigs as affected by high fibre diets fed after weaning
}

\author{
G. Skiba ${ }^{1}$, St. Raj, D. Weremko, H. Fandrejewski and J.Woliński \\ The Kielanowski Institute of Animal Physiology and Nutrition, Polish Academy of Sciences \\ 05-110 Jabłonna, Poland
}

\begin{abstract}
Two groups of gilts were fed from 10 to $25 \mathrm{~kg} \mathrm{BW}$ on a standard low fibre (LF) diet, and two groups on a LF diet supplemented with 10 or $20 \%$ grass meal ( MF and HF diet, respectively). The fibre content was 37.9, 53.5 and $76.4 \mathrm{~g} / \mathrm{kg}$ in the LF, MF and HF diets, respectively. At $25 \mathrm{~kg}$ BW the pigs from one group fed on LF, and groups on MF and HF diets, were assigned to the LF diet, while a second group fed on LF was transferred to the HF diet. After 14 days the pigs were slaughtered and samples of mucosa from the proximal, middle and distal part of the small intestine were taken and analysed for the activity of sucrase, aminopeptidase A and N, and dipepidyl peptidase IV. The activity of peptidases was higher in pigs fed MF and HF diets from 10 to $25 \mathrm{~kg}$ and the HF diet 14 days before slaughter than in animals continuously fed on the standard LF diet, while the activity of sucrase was higher in pigs fed on the MF diet from 10 to $25 \mathrm{~kg}$ than continuously on the LF diet.
\end{abstract}

KEY WORDS: piglets, fibre, enzyme activity

\section{INTRODUCTION}

Development of digestive-tract enzymatic functions in piglets around weaning is well known (Hedemann et al., 2003; Hedemann and Jensen, 2004). However, no information is available on the effects of feeding a high fibre diet after weaning on enzymatic function of the small intestine mucosa in pigs fed during the following period on a standard low fibre diet.

The objective of the study was to determine the effect of temporary fibre supplementation of diets fed to piglets after weaning, on the activity of sucrase and peptidases in the mucosa of the small intestine after a period of feeding a standard diet.

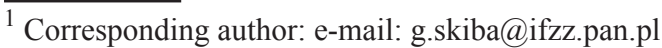




\section{MATERIAL AND METHODS}

The diets differing in fibre content were formulated by mixing a standard low fibre diet (LF) with 10 or $20 \%$ of grass meal (diet MF and HF, respectively). The crude fibre contents in diets LF, MF and HF were $37.9,53.5$ and $76.4 \mathrm{~g} / \mathrm{kg}$, respectively. The experiment was carried out with four litters of five gilts allotted after weaning to four groups, and comprised two periods. From 10 to $25 \mathrm{~kg} \mathrm{BW}$ the piglets were fed on diets differing in fibre contents, i.e. on LF (group 1 and 4), MF (group 2) or HF diets (group 3), and then were transferred for 14 days to the LF (group 1, 2 and 3) or to HF (group 4) diet (Table 1). After 14 days the pigs were slaughtered, the small intestine removed, separated from mesenteric fat, and divided into three equal sections: proximal, middle and distal. From each section a sample of mucosa was taken, frozen in liquid nitrogen and stored at $70^{\circ} \mathrm{C}$ until analysis. The activities of sucrase (Dahlquist, 1964), aminopeptidases A and N (Maroux et al., 1973) and dipepidyl peptidase (Nagatsu et al., 1976) were determined in mucosa homogenates.

Analysis of variance was performed using Statgraphics version 6.0 Plus software.

Table 1 . Enzyme activity of the small intestine mucosa (mmol/g mucosa) as affected by previous fibre diet

\begin{tabular}{|c|c|c|c|c|c|c|c|}
\hline \multirow{2}{*}{ Group } & \multirow{2}{*}{\multicolumn{2}{|c|}{$\begin{array}{l}\text { Diets fed in the period } \\
10-25 \mathrm{~kg} \text { BW } 14 \text { days }\end{array}$}} & \multirow{2}{*}{ Segments } & \multirow{2}{*}{ Sucrase } & \multicolumn{2}{|c|}{ Aminopeptidase } & \multirow{2}{*}{$\begin{array}{c}\text { Dipepidyl } \\
\text { peptidase IV }\end{array}$} \\
\hline & & & & & $\mathrm{A}$ & $\mathrm{N}$ & \\
\hline \multirow{3}{*}{1} & \multirow{3}{*}{ LF } & \multirow{3}{*}{$\mathrm{LF}$} & Proximal & 3.54 & 2.42 & 6.23 & 4.70 \\
\hline & & & Middle & 4.66 & 5.54 & 9.96 & 6.13 \\
\hline & & & Distal & 3.98 & 9.01 & 11.66 & 8.48 \\
\hline \multirow{3}{*}{2} & \multirow{3}{*}{ MF } & \multirow{3}{*}{$\mathrm{LF}$} & Proximal & 3.59 & 6.38 & 15.44 & 7.97 \\
\hline & & & Middle & 6.96 & 11.05 & 13.20 & 12.72 \\
\hline & & & Distal & 7.35 & 15.49 & 17.61 & 17.47 \\
\hline \multirow{3}{*}{3} & \multirow{3}{*}{$\mathrm{HF}$} & \multirow{3}{*}{$\mathrm{LF}$} & Proximal & 3.98 & 4.36 & 7.91 & 6.00 \\
\hline & & & Middle & 6.02 & 8.88 & 14.77 & 11.49 \\
\hline & & & Distal & 6.46 & 12.93 & 18.76 & 16.90 \\
\hline \multirow{3}{*}{4} & \multirow{3}{*}{$\mathrm{LF}$} & \multirow{3}{*}{$\mathrm{HF}$} & Proximal & 2.93 & 3.74 & 7.06 & 6.47 \\
\hline & & & Middle & 6.78 & 10.67 & 17.93 & 11.22 \\
\hline & & & Distal & 6.09 & 9.35 & 10.28 & 12.52 \\
\hline \multirow{3}{*}{\multicolumn{2}{|c|}{ Statistical significance }} & SEM & & 0.97 & 0.95 & 1.02 & 1.08 \\
\hline & & Group & & $*$ & $* *$ & $* *$ & $* *$ \\
\hline & & Segmer & & NS & $* *$ & $* *$ & $* *$ \\
\hline \multicolumn{4}{|c|}{ Interaction } & NS & NS & NS & NS \\
\hline
\end{tabular}

* $\mathrm{P}<0.05,{ }^{* *} \mathrm{P}<0.01$, NS - not significant 


\section{RESULTS AND DISCUSSION}

Sucrase activity was the lowest in pigs fed the standard low fibre diet in both periods (group 1, mean from three segments $4.06 \mathrm{mmol} / \mathrm{g}$ mucosa) and the highest in pigs fed on the MF diet followed by LF (group 2, mean $5.97 \mathrm{mmol} / \mathrm{g}$; $\mathrm{P}<0.05$; Table 1). Increasing the fibre content and feeding the high fibre diet in the period preceding slaughter (group 3 and 4, respectively) did not significantly affect sucrase activity. The activity of this enzyme was not significantly related to the segment of the intestine, but a tendency was observed towards lower activity in the proximal part than in the middle and distal ones.

Proteolytic enzyme activity was affected both by the segment of intestine and the diet. The activity of all aminopeptidases was greater in the middle and distal segments than in the proximal part. It was also higher in pigs from groups 2 and 3 fed on both diets with a higher fibre content from 10 to $25 \mathrm{~kg}$ body weight, and in group 4 fed on the high-fibre diet 14 days before slaughter. The increase of aminopeptidase activities was found in all segments.

The results indicate that feeding a diet with increased fibre for 14 days increases the enzymatic activity of intestinal mucosa. This may be considered a compensatory response of the digestive tract to the inhibitory effect of fibre on digestion of nutrients (Jørgensen et al., 1996). The considerably higher enzymatic activity of mucosa found in pigs after a 14-day period of feeding a low fibre diet, following feeding diets with a higher fibre content, points to a persistent effect of fibre on the digestive tract of young pigs.

\section{REFERENCES}

Dahlquist A., 1964. Assay of intestinal disaccharides. Scand. J. Lab. Invest. 44, 169-172

Hedemann M.S., Højsgaard S., Jensen B.B., 2003. Small intestinal morphology and activity of intestinal peptidases in piglets around weaning. J. Anim. Physiol. Anim. Nutr. 87, 32-41

Hedemann M.S., Jensen B.B., 2004. Variations in enzyme activity in stomach and pancreatic tissue and digesta in piglets around weaning. Arch. Anim. Nutr. 58, 47-59

Jørgensen H., Zhao X.Q., Eggum B.O., 1996. The influence of dietary fibre and environmental temperature on the development of the gastrointestinal tract, digestibility, degree of fermentation in the hind gut and energy metabolism in pigs. Brit. J. Nutr. 75, 365-378

Maroux S., Louvard M., Baratti J., 1973. The aminopeptidases from hog intestinal brush border. Biochim. Biophys. Acta 321, 282-295

Nagatsu T., Hino M., Fuyamada H., Hayakawa T., Sakakibara S., Nakagawa Y., Takemoto T., 1976. New chromogenic substrates for X-prolyl dipeptidyl-aminopetidase. Anal. Biochem. 74, 466-476 


\section{STRESZCZENIE}

\section{Aktywność enzymatyczna śluzówki jelita cienkiego prosiąt żywionych po odsadzeniu dietami z dużą zawartością włókna}

Dwie grupy loszek odsadzonych przy masie ciała $10 \mathrm{~kg}$ żywiono dietą standardową o niskiej zawartości włókna (LF), a dwie grupy dietą LF z dodatkiem 10 lub 20\% mączki z traw (odpowiednio dieta MF i HF). Zawartość włókna w diecie LF, MF i HF wynosiła odpowiednio 37,9; 53,5 i 76,4 $\mathrm{g} / \mathrm{kg}$. Po osiągnięciu $25 \mathrm{~kg}$ m.c. loszki z jednej grupy LF oraz z grup MF i HF żywiono dietą LF, zaś zwierzętom z drugiej grupy LF podawano dietę HF. Po 14 dniach świnie ubito, pobrano śluzówkę z trzech odcinków jelita cienkiego i oznaczono aktywność sacharazy, aminopeptydazy A i N oraz dipepidyl peptydazy IV. Aktywność peptydaz była wyższa u świń żywionych dietami MF i HF od m.c. 10 do $25 \mathrm{~kg}$ oraz dietą HF przez 14 dni przed ubojem, niż u zwierząt żywionych przez cały czas doświadczenia dietą LF. Aktywność sacharazy była wyższa u świń żywionych dietą MF od 10 do $25 \mathrm{~kg}$ m.c. niż otrzymujących przez cały czas dietę LF. 